\title{
Efficient Synthetic Method of Z-Selective 2-Halo-1,3-dienes from Reactions of Allenols Possessing Ethoxycarbonyl and Vinyl Group with Indium Trihalide ${ }^{\dagger}$
}

\author{
Dahan Eom, Sung Hong Kim, and Phil Ho Lee* \\ Department of Chemistry and Institute for Molecular Science and Fusion Technology, Kangwon National University, \\ Chuncheon 200-701, Korea.*E-mail: phlee@kangwon.ac.kr \\ ${ }^{*}$ Analysis Research Division Daegu Center, Korea Basic Science Institute, Daegu 702-701, Korea \\ Received September 16, 2009, Accepted October 4, 2009
}

\begin{abstract}
An efficient synthetic method of Z-selective 3-ethoxycarbonyl-2-halo-1,3-dienes and 3-vinyl-2-halo-1,3-dienes was developed from the reaction of allenols having ethoxycarbonyl and vinyl group with indium trihalides at room temperature in $\mathrm{CH}_{2} \mathrm{Cl}_{2}$.
\end{abstract}

Key Words: Allenol, 2-Halo-1,3-diene, Indium trihalide, Selectivity

\section{Introduction}

The development of efficient and versatile strategies for the synthesis of 1,3-dienes continues to be of major significance in synthetic organic chemistry. ${ }^{1}$ In this regard, transformations of readily available substrates to functionalized 1,3-dienes are highly desirable. Especially, 2-halo-1,3-dienes have been received much attentions as very important precursors due to the possibility of further functionalization of vinyl halide before or after Diels-Alder reaction. Bäckvall et al. described stereoconvergent synthesis of $(Z, E)$-2-bromo-1,3-dienes from $\operatorname{Pd}(\mathrm{II})$-catalyzed $S_{N} 2^{\prime}$ reactions of $\alpha$-allenic acetates. ${ }^{2}$ Ma et al. developed $S_{N} 2^{\prime}$-type addition-elimination reactions of 1-aryl2,3-allenols with $\mathrm{LiX}^{3}{ }^{3}$ stereoselective addition-elimination reactions of 3-(methoxycarbonyl)-1,2-allen-4-ols with MX (M: $\mathrm{Na}, \mathrm{Li}, \mathrm{K} . \mathrm{X}: \mathrm{Cl}, \mathrm{Br}, \mathrm{I}){ }^{4}$ and regio- and stereoselective reactions of 2-(methoxycarbonyl)-2,3-allenols with oxalyl chloride in DMSO, affording 2-halo-1,3-dienes. ${ }^{5}$ Also, Cho et al . found indium trihalide-mediated $S_{N} 2^{\prime}$ reaction of alkyl- or arylsubstituted allenols to produce 2-halo-1,3-dienes. ${ }^{6}$ However, there still remains a significant need for more direct methods to afford functionalized 1,3-diene derivatives. Recently, we developed not only the efficient synthetic method of a variety of allenols having ethoxycarbonyl group ${ }^{7}$ but also Diels-Alder reactions of 2-azetidinones having 1,3-butadien-2-yl ${ }^{8}$ and 1,2,4,5-hexa-tetraen-3-yl group at the 4-position. ${ }^{9}$ During the course of our research program aimed at finding new indiummediated organic reactions, ${ }^{10}$ we became interested in the stereo-

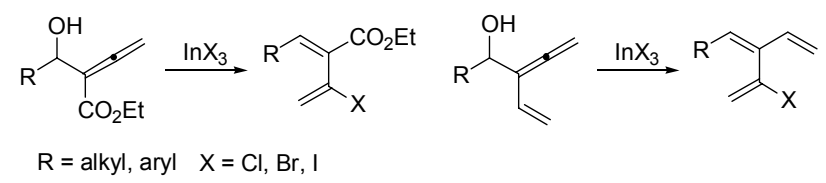

Scheme 1. Synthesis of 2-halo-1,3-dienes through reaction of allenols possessing ethoxycarbonyl and vinyl group with indium trihalide

${ }^{\dagger}$ This paper is dedicated to Professor Sunggak Kim on the occasion of his honorable retirement. selective synthesis of 2-halo-1,3-dienes from allenols bearing an ethoxycarbonyl or vinyl group. ${ }^{11}$ Herein, we report a stereoselective synthetic method of 2-halo-1,3-dienes from the reaction of allenols possessing ethoxycarbonyl or vinyl group with indium trihalide (Scheme 1).

\section{Results and Discussion}

Preparation of allenols possessing ethoxycarbonyl and vinyl group. Allenols having ethoxycarbonyl group were regioselectively obtained from the reaction of aldehydes ( 1 equiv) with organoindium reagent generated in situ from indium (1 equiv) and ethyl 4-bromobutynoate (1.5 equiv) in the presence of LiI (1.5 equiv) in DMF (eq. 1). ${ }^{7}$ Reactions of aldehyde ( 1 equiv) with organoindium reagent generated in situ from 1-bromopent4-en-2-yne (2, 1 equiv) ${ }^{12}$ and indium (1 equiv) in the presence of LiI (1 equiv) gave selectively allenols having vinyl group in THF at $25^{\circ} \mathrm{C}$ for $2 \mathrm{~h}$ (eq. 2). ${ }^{13}$

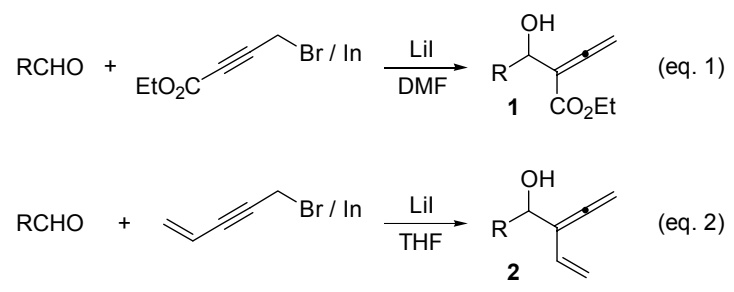

Reactions of allenols possessing ethoxycarbonyl group with indium trihalide. First, reaction of ethoxycarbonyl allenols with a variety of Lewis acids were examined (Table 1). Treatment of 1 a with TMSOTf, $\operatorname{In}(\mathrm{OTf})_{3}$ and $\mathrm{BF}_{3} \cdot \mathrm{OEt}_{2}$ gave a mixture of ethyl $(E)$-2-ethynyl cinnamate (4) ${ }^{14}$ and ethyl $(E)$-2-acetyl cinnamate (5) (entries 1-3). Although $\mathrm{ZnCl}_{2}$ did not react with $\mathbf{1 a}$ (entry 4), $\mathrm{AlCl}_{3}$ gave ethyl (Z)-2-(1'-chlorovinyl)cinnamate (3a) in $23 \%$ yield and ethyl 2-benzhydroxyl-3-chloro-3-butenoate (6) in 23\% yield (entry 5). In the case of AgOTf, 3-ethoxycarbonyl-2-phenyl-2,5-dihydrofuran (7) was produced in 57\% yield (entry 6). Next, we examined the reaction of 19 with in- 
dium trihalide as Lewis acid. Treatment of $1 \mathbf{a}$ with 1 equiv of $\mathrm{InCl}_{3}$ produced 2-chloro-1,3-diene $\mathbf{3 a}(Z: E=36: 1)$ in $71 \%$ yield and ethyl 2-acetylcinnamate (5) in $6 \%$ yield at $25^{\circ} \mathrm{C}$ for $5 \mathrm{~h}$ in $\mathrm{CH}_{2} \mathrm{Cl}_{2}$ (entry 7). The stereochemistry $(Z / E)$ of double bond was determined by comparison to the corresponding methyl ester. $^{4}$ The chemical shift $(\delta 7.70)$ of vinyl proton on benzylic position of Z-3a was downfield than that ( $\delta 7.21)$ of $E-\mathbf{3 a}$.<smiles>C=C(Cl)/C(=C\c1cccnc1)C(=O)OC</smiles>

(Z)<smiles>C=C(Cl)/C(=C\c1cccnc1)C(=O)OCC</smiles>

(Z-3a)<smiles>C=C(Cl)/C(=C\c1ccccc1)C(=O)OCC</smiles>

(E-3a)
Compound 1a reacted with 1 equiv of $\mathrm{InBr}_{3}$ and $\mathrm{InI}_{3}$ to afford 2-bromo-1,3-diene 3b (84\%, Z:E=39:1) and 2-iodo-1,3-diene 3c $(79 \%, Z: E=55: 1)$, respectively (entries 9 and 10$)$. The use of $\mathrm{InCl}_{3}(0.34$ equiv) provided 3a in $51 \%$ yield $(Z: E=50: 1)$ (entry 8). Reaction of $\mathbf{1 a}$ with $\mathrm{LiCl}$ ( 3 equiv) did not proceed without In $\mathrm{X}_{3}$ in $\mathrm{CH}_{2} \mathrm{Cl}_{2}$ (entry 11). Use of catalytic amount (0.1 equiv) of $\mathrm{InCl}_{3}$ and $\mathrm{LiCl}$ (3 equiv) was not effective for the reaction with $1 \mathrm{a}$ in $\mathrm{CH}_{2} \mathrm{Cl}_{2}$ or DMF (entries 12 and 13). Dichloromethane was the best solvent among several reaction media screened (DMF, benzene and $\mathrm{CH}_{3} \mathrm{CN}$ ). Although the use of benzene as a solvent gave good $E / Z$ selectivity $(182: 1)$ at $25{ }^{\circ} \mathrm{C}$ for $10 \mathrm{~h}$ (entry 14), the starting material 1a did not completely disappear in spite of refluxing condition. Of the reactions screen-

Table 1. Reaction of ethoxycarbonyl allenols with Lewis acids

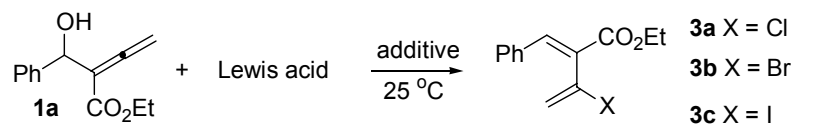

\begin{tabular}{|c|c|c|c|c|c|}
\hline entry & $\begin{array}{c}\text { Lewis acid } \\
\text { (equiv) }\end{array}$ & $\begin{array}{c}\text { additive } \\
\text { (equiv) }\end{array}$ & solvent & $\begin{array}{l}\text { time } \\
\text { (h) }\end{array}$ & yield $^{a}(\%)$ \\
\hline $1^{b}$ & $\operatorname{TMSOTf}(0.2)$ & - & $\mathrm{CH}_{2} \mathrm{Cl}_{2}$ & 5 & $(55)^{c}(20)^{d}$ \\
\hline 2 & $\operatorname{In}(\mathrm{OTf})_{3}(1)$ & - & $\mathrm{CH}_{2} \mathrm{Cl}_{2}$ & 5 & $(37)^{c}(16)^{d}$ \\
\hline $3^{b}$ & $\mathrm{BF}_{3} \cdot \mathrm{OEt}_{2}(1)$ & - & $\mathrm{CH}_{2} \mathrm{Cl}_{2}$ & 0.17 & $(17)^{c}(44)^{d}$ \\
\hline 4 & $\mathrm{ZnCl}_{2}(1)$ & - & $\mathrm{CH}_{2} \mathrm{Cl}_{2}$ & 24 & $(95)^{e}$ \\
\hline 5 & $\mathrm{AlCl}_{3}(1)$ & - & $\mathrm{CH}_{2} \mathrm{Cl}_{2}$ & 10 & $23(23)^{f}$ \\
\hline 6 & $\operatorname{AgOTf}(1)$ & - & $\mathrm{CH}_{2} \mathrm{Cl}_{2}$ & 3 & $(57)^{g}$ \\
\hline 7 & $\mathrm{InCl}_{3}(1)$ & - & $\mathrm{CH}_{2} \mathrm{Cl}_{2}$ & 5 & $71(36: 1)^{h}(6)^{d}$ \\
\hline 8 & $\mathrm{InCl}_{3}(0.34)$ & - & $\mathrm{CH}_{2} \mathrm{Cl}_{2}$ & 10 & $51(50: 1)^{h}(15)^{d}(10)^{e}$ \\
\hline 9 & $\mathrm{InBr}_{3}(1)$ & - & $\mathrm{CH}_{2} \mathrm{Cl}_{2}$ & 2 & $84(39: 1)^{h}$ \\
\hline 10 & $\operatorname{Inl}_{3}(1)$ & - & $\mathrm{CH}_{2} \mathrm{Cl}_{2}$ & 2 & $79(55: 1)^{h}$ \\
\hline 11 & - & $\mathrm{LiCl}(3)$ & $\mathrm{CH}_{2} \mathrm{Cl}_{2}$ & 10 & 0 \\
\hline 12 & $\mathrm{InCl}_{3}(0.1)$ & $\mathrm{LiCl}(3)$ & $\mathrm{CH}_{2} \mathrm{Cl}_{2}$ & 20 & 0 \\
\hline 13 & $\mathrm{InCl}_{3}(0.1)$ & $\mathrm{LiCl}(3)$ & DMF & 10 & 0 \\
\hline 14 & $\mathrm{InCl}_{3}(1)$ & - & benzene & 10 & $47(182: 1)^{h}$ \\
\hline 15 & $\mathrm{InCl}_{3}(1)$ & - & $\mathrm{CH}_{3} \mathrm{CN}$ & 10 & 0 \\
\hline 16 & $\mathrm{InCl}_{3}(1)$ & - & DMF & 10 & 0 \\
\hline 17 & $\mathrm{InCl}_{3}(1.5)$ & - & $\mathrm{CH}_{2} \mathrm{Cl}_{2}$ & 4 & $81(78: 1)^{h}$ \\
\hline 18 & $\mathrm{InI}_{3}(1.5)$ & - & $\mathrm{CH}_{2} \mathrm{Cl}_{2}$ & 1 & $89(35: 1)^{h}$ \\
\hline
\end{tabular}

${ }^{a}$ Isolated yield. ${ }^{b}$ Reaction was carried out at $0{ }^{\circ} \mathrm{C}$. ${ }^{c}$ Ethyl $(E)$-2-ethynyl cinnamate (4). ${ }^{d}$ Ethyl (E)-2-acetyl cinnamate (5). ${ }^{e}$ 1a. ${ }^{f}$ Ethyl 2-benzhydroxyl3-chloro-3-butenoate (6). ${ }^{g}$ 3-Ethoxycarbonyl-2-phenyl-2,5-dihydrofuran. (7). ${ }^{h} Z / E$ ratio ed, the best results were obtained from the reaction of $1 \mathrm{a}$ with $\mathrm{InCl}_{3}$ (1.5 equiv), $\mathrm{InBr}_{3}$ (1.0 equiv) and $\mathrm{InI}_{3}$ ( 1.5 equiv), producing 3a, 3b and 3c in 81\% $(Z: E=78: 1), 84 \%(Z: E=39: 1)$ and $89 \%(Z: E=35: 1)$ yields (entries 17,9 and 18$)$.

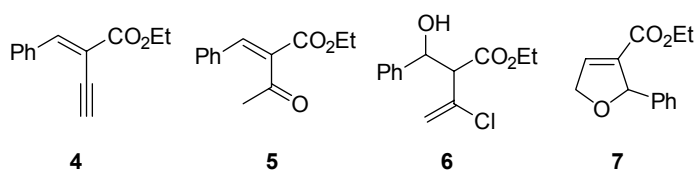

Table 2. Synthesis of 3-ethoxycarbonyl-2-halo-1,3-dienes from the reactions of ethoxycarbonyl allenols with indium trihalides ${ }^{a}$

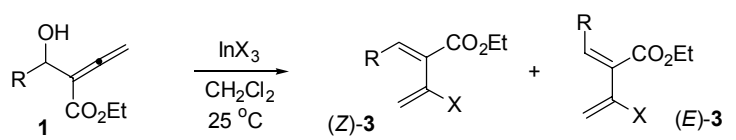

\begin{tabular}{|c|c|c|c|c|c|}
\hline entry & allenol & $\begin{array}{c}\text { time } \\
\text { (h) }\end{array}$ & product & $\mathrm{X}$ & $\begin{array}{c}\text { yield }^{b} \\
(\%)\end{array}$ \\
\hline
\end{tabular}

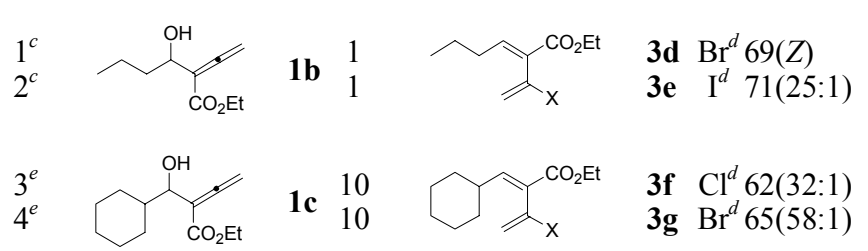
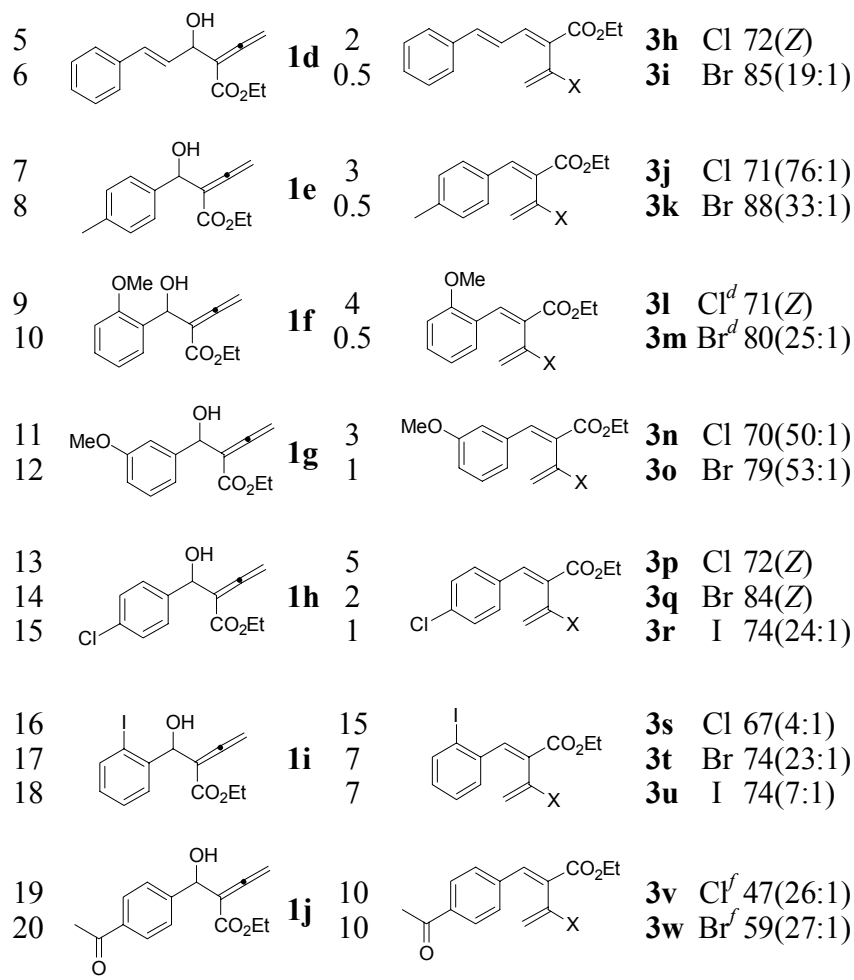
22

${ }^{a}$ Reactions were carried out with $\operatorname{In} \mathrm{X}_{3}$ ( 1 equiv) at $25^{\circ} \mathrm{C}$. ${ }^{b}$ Ratio in parenthesis indicates ratio of $Z / E$ isomer determined from NMR. ${ }^{c}$ Reaction was carried out $80{ }^{\circ} \mathrm{C} .{ }^{d} \operatorname{In} \mathrm{X}_{3}$ (1.5 equiv) was used. ${ }^{e}$ Reaction was carried out $40{ }^{\circ} \mathrm{C} .{ }^{f} \operatorname{InX} \mathrm{X}_{3}$ (2 equiv) was used. 
Table 3. Synthesis of 2-halo-1,3-dienes from the reaction of vinyl allenols with indium trihalide ${ }^{a}$<smiles>[R]C(O)C(=C)C=C</smiles>

$$
\underset{\underset{25}{{ }^{\circ} \mathrm{C}}}{\stackrel{\mathrm{InX}}{\mathrm{CH}_{3} \mathrm{Cl}_{2}}}
$$

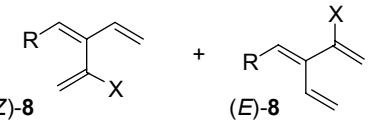

\begin{tabular}{cccc}
\hline entry allenol & $\begin{array}{c}\text { time } \\
(\mathrm{min})\end{array} \quad$ product & $\begin{array}{r}\text { yield }^{b} \\
(\%)\end{array}$
\end{tabular}$$
1
$$<smiles>C=CC(=C)C(O)C1CCCCC1</smiles>

2a 30

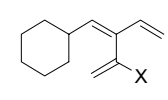

8a $\operatorname{Br}^{c} 56(4.4: 1)$

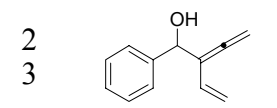

2b 10

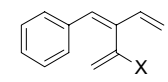

8b $\quad \mathrm{Cl} 72(2.3: 1)$

8c $\operatorname{Br} 68(1.4: 1)$

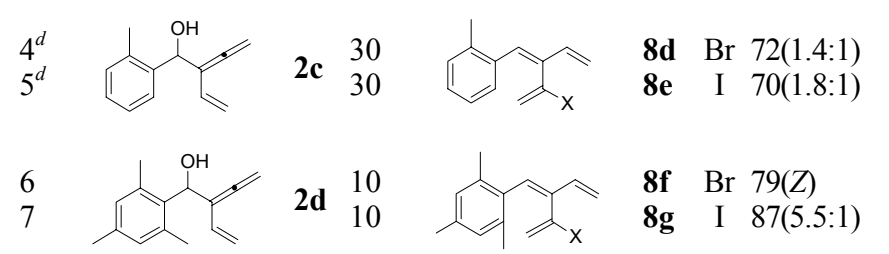

8<smiles>C=CC(=C)C(O)c1cccc(O)c1</smiles>

2e 10

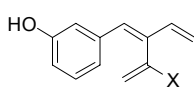

8h $\operatorname{Br}^{c} 70(1.9: 1)$

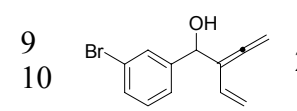

2f $\begin{gathered}120 \\ 30\end{gathered}$

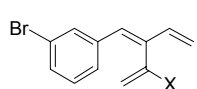

8i $\mathrm{Cl} 70(2: 1)$

8j $\operatorname{Br} 61(1.4: 1)$
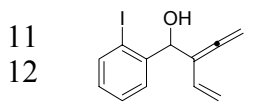

2g $\begin{gathered}160 \\ 50\end{gathered}$

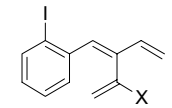

8k Cl 61(2.4:1)

$81 \mathrm{Br} 52(3.2: 1)$

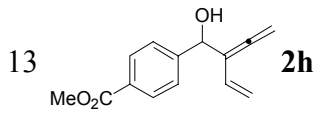

20

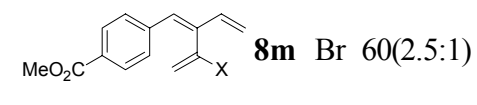

${ }^{a}$ Reactions were carried out with $\operatorname{InX}_{3}$ (1 equiv). ${ }^{b}$ Isolated yield. Ratio in parenthesis indicates $Z / E$ isomer determined from $\mathrm{NMR}^{c}{ }^{c} \operatorname{InBr}_{3}$ ( 1.5 equiv) was used. ${ }^{d}$ Reaction was carried out at $0{ }^{\circ} \mathrm{C}$.

To demonstrate the efficiency and scope of the present method, we carried out the reactions of a variety of ethoxycarbonyl allenols $\mathbf{1}$ with indium trihalide (Table 2). Reaction of $\mathbf{1} \mathbf{b}$ obtained from butanal with 1.5 equiv of $\mathrm{InBr}_{3}$ and $\mathrm{InI}_{3}$ afforded stereoselectively 2-halo-1,3-dienes $3 \mathbf{d}$ and $3 \mathbf{e}$ in $69 \%$ ( $Z$ only) and $71 \%(Z: E=25: 1)$ yields, respectively, at $80^{\circ} \mathrm{C}$ for $1 \mathrm{~h}$ (entries 1 and 2). Treatment of $1 \mathbf{c}$ with $\mathrm{InCl}_{3}$ and $\mathrm{InBr}_{3}$ gave rise to the desired products $\mathbf{3 f}(Z: E=32: 1)$ and $\mathbf{3 g}(Z: E=58: 1)$ in good yields (entries 3 and 4 ). Allenol $1 \mathbf{d}$ derived from cinnamaldehyde reacted with indium trihalide (1 equiv) to produce stereoselectively 2-halo-1,3-dienes $3 \mathbf{h}$ and $3 \mathbf{i}$ in $72 \%$ ( $Z$ only) and $85 \%$ ( $Z: E=19: 1$ ) yields, respectively (entries 5 and 6 ). Electronic as well as steric variations on the aromatic substituents such as methyl, methoxy, chloro, iodo, acetyl and methoxycarbonyl displayed little effect on the reaction efficiency and selectivity (entries 7-22). Treatment of ethoxycarbonyl allenols (1f and $\mathbf{1 g}$ ) having methoxy group on aromatic ring afforded the desired

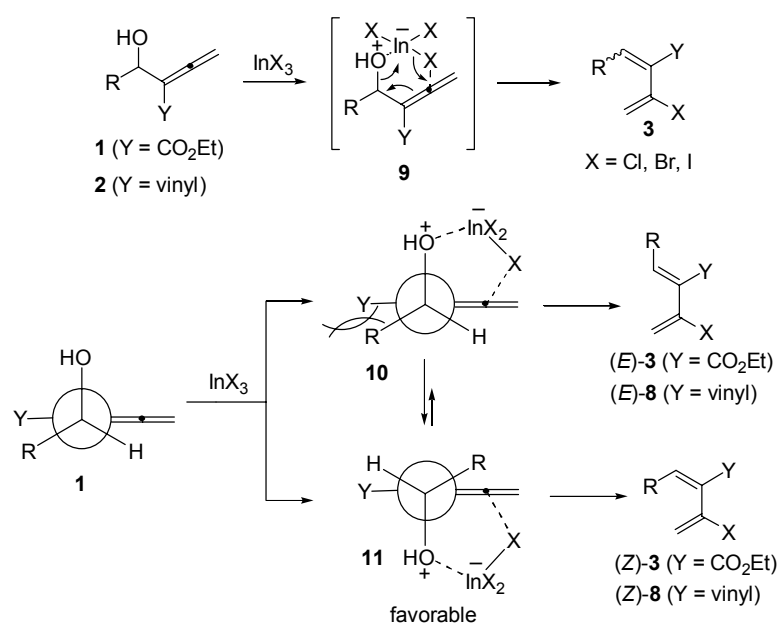

Scheme 2. A plausible mechanism

2-halo-1,3-dienes in good yields (entries 9-12). We were pleased to obtain selectively ( $Z$ )-2-chloro and 2-bromo-1,3-diene (3p and 3q) from the reaction of $\mathbf{1 h}$ with $\mathrm{InCl}_{3}$ and $\mathrm{InBr}_{3}$ (entries 13 and 14). However, $Z$-selectivity $(Z: E=24: 1)$ was a little bit lower in the case of $\operatorname{InI}_{3}$ (entry 15). Allenol 1i obtained from 2iodobenzaldehyde participated in the reaction well (entries 1618). Although the reactions worked equally well with ethoxycarbonyl allenol $1 \mathrm{k}$ possessing methoxycarbonyl group on the aromatic ring to give the desired products ( $3 \mathbf{x}$ and $\mathbf{3 y}$ ) in $71 \%$ and $77 \%(Z: E=17: 1)$ yields (entries 21 and 22$)$, allenol $\mathbf{1 j}$ having ketone group produced 2-halo-1,3-dienes ( $3 \mathbf{v}$ and $\mathbf{3 w})$ in lower yields ( $47 \%$ and $59 \%$ ), indicating that indium trihalide might complex with ketone group (entries 19 and 20). ${ }^{15}$

Reactions of allenols possessing vinyl group with indium trihalide. First, reactions of various vinyl allenols 2 with indium trihalide were examined (Table 3). Treatment of $\mathbf{2 a}$ derived from cyclohexanecarboaldehyde with 1.5 equiv of $\mathrm{InBr}_{3}$ produced 2-bromo-1,3-diene 8a in $56 \%(Z: E=4.4: 1)$ yield at $25^{\circ} \mathrm{C}$ for 30 min in dichloromethane (entry 1). Reaction of $\mathbf{2} \mathbf{b}$ with $\mathrm{InCl}_{3}$ and $\mathrm{InBr}_{3}$ afforded the desired products $\mathbf{8 b}(Z: E=2.3: 1)$ and $8 \mathbf{c}(Z: E=1.4: 1)$ in $72 \%$ and $68 \%$ yields, respectively (entries 2 and 3). Vinyl allenol $\mathbf{2} \mathbf{c}$ obtained from $o$-tolualdehyde and organoindium reagen ${ }^{13}$ generated in situ from indium and 1-bromo4-penten-2-yne work equally well with the employed reaction conditions, producing the 2-bromo-1,3-dienes $8 \mathbf{d}$ and $8 \mathrm{e}$ in $72 \%$ and $70 \%$ yields at $0{ }^{\circ} \mathrm{C}$, respectively (entries 4 and 5). We were pleased to obtain selectively $\mathbf{8 f}$ in $79 \%$ yield under the optimum conditions (entry 6). In the case of vinyl allenol 2e generated from 3-hydroxybenzaldehyde, 2-bromo-1,3-diene $\mathbf{8 h}$ was produced in $70 \%(Z: E=1.9: 1)$ yield with 1.5 equiv of $\operatorname{InBr}_{3}$ (entry 8). Subjecting vinyl allenol $\mathbf{2 f}$ and $\mathbf{2 g}$ having bromo- and iodophenyl group to $\mathrm{InCl}_{3}$ and $\mathrm{InBr}_{3}$ resulted in formation of the corresponding 2-bromo- and iodo-1,3-dienes $(\mathbf{8 i}, \mathbf{8 j}, \mathbf{8 k}$ and $\mathbf{8 I})$ in moderate to good yields (entries 9-12). Bromo vinyl allenol 8m was obtained in $60 \%$ yield from the reaction of vinyl allenol $\mathbf{2 h}$ with $\mathrm{InBr}_{3}$ (entry 13).

Reaction mechanism. Although mechanism for the reaction of allenol having ethoxycarbonyl or vinyl group with indium trihalide has not been firmly established, the present reaction 
can be described as in Scheme 2. First, indium trihalide coordinates with allenol $\mathbf{1}$ or $\mathbf{2}$ to form a six membered cyclic transition state 9 and then, subsequent $S_{N} 2$ ' attack of the halide ion to the center carbon of allene resulted in 2-halo-1,3-dienes 3 . The major isomer $(Z)-\mathbf{3}$ or $\mathbf{8}$ might be produced through more favorable transition state $\mathbf{1 1}$ compared to $\mathbf{1 0}$ due to steric interaction between aryl or alkyl and ethoxycarbonyl or vinyl group. Allenols having vinyl group gave low $Z / E$ selectivity rather than that bearing ethoxycarbonyl group. ${ }^{6}$ Although we do not know exact reason on the different stereoselectivity for the formation of $\mathbf{3}$ and $\mathbf{8}$, we think that intramolecular hydrogen bonding between carbonyl and hydroxyl group in allenols having ethoxycarbonyl group might increase stability and rigidity of intermediate (10 and 11), giving better selectivity rather than that of allenol having vinyl group.

\section{Conclusion}

In summary, we have described an efficient synthetic method of $Z$-selective 3-ethoxycarbonyl-2-halo-1,3-dienes from the reaction of allenols having ethoxycarbonyl with indium trihalides $\left(\mathrm{InCl}_{3}, \mathrm{InBr}_{3}\right.$, and $\left.\mathrm{InI}_{3}\right)$ in $\mathrm{CH}_{2} \mathrm{Cl}_{2}$ at room temperature. Also, 3vinyl-2-halo-1,3-dienes were produced in moderate to good yields from the treatment of vinyl allenols with indium trihalides ( $\mathrm{InCl}_{3}$ and $\mathrm{InBr}_{3}$ ) in $\mathrm{CH}_{2} \mathrm{Cl}_{2}$. Because the 2-halo-1,3-dienes can be applied to further functionalization such as Diels-Alder reactions and metal-catalyzed cross-coupling reactions, these results should provide more opportunities for the discovery of efficient and selective organic reactions.

\section{Experimental}

General section. Reactions were carried out in oven-dried glassware under nitrogen atmosphere. All commercial reagents were used without purification, and all solvents were reaction grade. DMF and $\mathrm{CH}_{2} \mathrm{Cl}_{2}$ were freshly distilled from $\mathrm{CaH}_{2}$. THF was freshly distilled from sodium/benzophenone under nitrogen. Indium powder (100 mesh, 99.99\%, Cat. No. 26,403-2) was purchased from Aldrich Chem Co. All reaction mixtures were magnetically stirred and were monitored by thin-layer chromatography using Merck silica gel $60 \mathrm{~F}_{254}$ precoated glass plates, which were visualized with UV light and then, developed using either iodine or a solution of anisaldehyde. Flash column chromatography was carried out using Merck silica gel 60 (0.040 $0.063 \mathrm{~mm}, 230$ - $400 \mathrm{mesh}) .{ }^{1} \mathrm{HNMR}$ and ${ }^{13} \mathrm{C}$ NMR spectra were recorded on a Brucker DPX FT ( $400 \mathrm{MHz}$ ) spectrometer. Deuterated chloroform was used as the solvent, and chemical shift values $(\delta)$ are reported in parts per million relative to the residual signals of this solvent $\left(\delta 7.24\right.$ for ${ }^{1} \mathrm{H}$ and $\delta 77.0$ for $\left.{ }^{13} \mathrm{C}\right)$. Infrared spectra were recorded on a JASCO FT/IR-460 plus FT-IR spectrometer as either a thin film pressed between two sodium chloride plates or as a solid suspended in a potassium bromide disk. Mass spectral data were obtained from the Korea Basic Science Institute (Daegu) on a Jeol JMS 700 high resolution mass spectrometer.

Synthetic procedure of ethyl 2-(hydroxyphenylmethyl)buta-2,3-dienoate (1a): ${ }^{7}$ Ethyl 4-bromobutynoate $(95.5 \mu \mathrm{L}, 0.75$ $\mathrm{mmol})$ was added to a suspension of indium $(57.4 \mathrm{mg}, 0.5 \mathrm{mmol})$ and LiI (200.8 mg, $1.5 \mathrm{mmol})$ in DMF (2.0 mL). After being stirred for $30 \mathrm{~min}$ at room temperature, benzaldehyde $(50.7 \mu \mathrm{L}$, $0.5 \mathrm{mmol}$ ) was added and then, the reaction mixture was stirred for $5 \mathrm{~h}$. The reaction mixture was quenched with saturated $\mathrm{NaH}-$ $\mathrm{CO}_{3}(20 \mathrm{~mL})$. The aqueous layer was extracted with diethyl ether $(3 \times 20 \mathrm{~mL})$. The combine organic layer was washed with brine, dried over $\mathrm{MgSO}_{4}$, filtered, and concentrated under reduced pressure. The residue was purified by silica gel column chromatography (ethyl acetate:hexane=1:5) to give ethyl 2-(hydroxyphenyl-methyl)buta-2,3-dienoate (1a) $(93.8 \mathrm{mg}, 86 \%$ ).

Ethyl 2-(hydroxyphenylmethyl)buta-2,3-dienoate (1a): Colorless oil; ${ }^{1} \mathrm{H}$ NMR $\left(400 \mathrm{MHz}, \mathrm{CDCl}_{3}\right) \delta$ 7.42-7.26 (m, 5H), $5.61(\mathrm{~d}, J=6.29 \mathrm{~Hz}, 1 \mathrm{H}), 5.19(\mathrm{~s}, 2 \mathrm{H}), 4.22(\mathrm{q}, J=7.14 \mathrm{~Hz}, 2 \mathrm{H})$, $3.49(\mathrm{~d}, J=6.29 \mathrm{~Hz}, 1 \mathrm{H}), 1.24(\mathrm{t}, J=7.14 \mathrm{~Hz}, 3 \mathrm{H}) ;{ }^{13} \mathrm{C} \mathrm{NMR}$ $\left(100 \mathrm{MHz}, \mathrm{CDCl}_{3}\right) \delta 213.4,167.2,141.8,128.6,128.1,126.7$, 104.1, 81.4, 72.3, 61.8, 14.5; IR (film) 3434, 2983, 1964, 1705, $1454,1368,1253,1039,699 \mathrm{~cm}^{-1}$.

Synthetic procedure of ethyl 2-(1-chlorovinyl)cinnamate (3a): Allenol 1a (65.5 mg, $0.3 \mathrm{mmol})$ was added to a solution of $\mathrm{InCl}_{3}(66.5 \mathrm{mg}, 0.3 \mathrm{mmol})$ in $\mathrm{CH}_{2} \mathrm{Cl}_{2}(1.2 \mathrm{~mL})$ at room temperature. After being stirred for $5 \mathrm{~h}$, the reaction was quenched with $\mathrm{NaHCO}_{3}(20 \mathrm{~mL})$ and extracted with $\mathrm{CH}_{2} \mathrm{Cl}_{2}$. The extract was washed with brine and dried over anhydrous $\mathrm{MgSO}_{4}$. The solvent was evaporated under reduced pressure. The residue was purified by silica gel column chromatography (ethyl acetate:hexane $=1: 5)$ to give ethyl 2-(1-chlorovinyl)cinnamate (50.0 mg, 71\%).

Ethyl (Z)-2-(1-chlonovinyl)cinnamate (3a-Z): Yellow oil; ${ }^{1} \mathrm{H}$ NMR (400 MHz, $\left.\mathrm{CDCl}_{3}\right) \delta 7.70(\mathrm{~s}, 1 \mathrm{H}), 7.66-7.64(\mathrm{~m}, 2 \mathrm{H})$, $7.40-7.37(\mathrm{~m}, 3 \mathrm{H}), 5.61(\mathrm{~d}, J=1.5 \mathrm{~Hz}, 1 \mathrm{H}), 5.36(\mathrm{~d}, J=1.5 \mathrm{~Hz}$, $1 \mathrm{H}), 4.32$ (q, $J=7.2 \mathrm{~Hz}, 2 \mathrm{H}), 1.36$ (t, $J=7.2 \mathrm{~Hz}, 3 \mathrm{H}) ;{ }^{13} \mathrm{C} \mathrm{NMR}$ $\left(100 \mathrm{MHz}, \mathrm{CDCl}_{3}\right) \delta 165.6,141.9,134.1,133.5,130.5,130.1$, 129.8, 128.9, 118.9, 61.5, 14.2; IR (film) 2981, 1715, 1649, $1608,1448,1253,1200,777 \mathrm{~cm}^{-1}$; LRMS (EI): calcd for $\mathrm{C}_{13} \mathrm{H}_{13}$ $\mathrm{ClO}_{2}$ 236.06, found 236.09.

Ethyl (E)-2-(1-chlorovinyl)cinnamate (3a-E): Yellow oil; ${ }^{1} \mathrm{H}$ $\operatorname{NMR}\left(400 \mathrm{MHz}, \mathrm{CDCl}_{3}\right) \delta$ 7.34-7.33 (m, 5H), $7.21(\mathrm{~s}, 1 \mathrm{H}), 5.59$ $(\mathrm{d}, J=2.2 \mathrm{~Hz}, 1 \mathrm{H}), 5.53(\mathrm{~d}, J=2.2 \mathrm{~Hz}, 1 \mathrm{H}), 4.24(\mathrm{q}, J=7.1 \mathrm{~Hz}$, 2H), $1.18(\mathrm{t}, J=7.1 \mathrm{~Hz}, 3 \mathrm{H}) ;{ }^{13} \mathrm{C} \mathrm{NMR}\left(100 \mathrm{MHz}, \mathrm{CDCl}_{3}\right) \delta$ 165.6, 141.9, 134.1, 133.9, 130.1, 129.8, 128.9, 128.5, 115.9, 61.8, 13.7; IR (film) 2981, 1715, 1649, 1608, 1448, 1253, 1200, $777 \mathrm{~cm}^{-1}$; LRMS (EI): calcd for $\mathrm{C}_{13} \mathrm{H}_{13} \mathrm{ClO}_{2} 236.06$, found 236.09.

Synthetic procedure of 1-phenyl-2-vinyl-2,3-butadien-1-ol (2b): ${ }^{13}$ 1-Bromopent-4-en-2-yne (72.5 mg, $\left.0.5 \mathrm{mmol}\right)$ was added to suspension of indium ( $57.4 \mathrm{mg}, 0.5 \mathrm{mmol})$ and lithium iodide $(66.9 \mathrm{mg}, 0.5 \mathrm{mmol})$ in dry THF $(2 \mathrm{~mL})$. After being stirred for 30 min at room temperature under nitrogen atmosphere, benzaldehyde ( $53.1 \mathrm{mg}, 0.5 \mathrm{mmol}$ ) was added. After $2 \mathrm{~h}$, the reaction mixture was quenched with saturated $\mathrm{NaHCO}_{3}$. The aqueous layer was extracted with $\mathrm{Et}_{2} \mathrm{O}(3 \times 20 \mathrm{~mL})$ and the combined organic layers were washed with brine, dried over $\mathrm{MgSO}_{4}$, filtered, and concentrated under reduced pressure. The residue was purified by silica gel column chromatography (ethyl acetate: hexane $=1: 10$ ) to give 1-phenyl-2-vinyl-2,3-buta-dien-1-ol (75.8 mg, 88\%).

1-Phenyl-2-vinyl-2,3-butadien-1-ol (2b): Yellow oil; ${ }^{1} \mathrm{H}$ NMR (400 MHz, $\left.\mathrm{CDCl}_{3}\right) \delta$ 7.42-7.27 (m, 5H), 6.11 (dd, $J=$ 
17.6, $10.8 \mathrm{~Hz}, 1 \mathrm{H}), 5.40(\mathrm{~s}, 1 \mathrm{H}), 5.22(\mathrm{~d}, J=17.6 \mathrm{~Hz}, 1 \mathrm{H})$, 5.18-5.10 (m, 2H), 5.08, (d, $J=10.8 \mathrm{~Hz}, 1 \mathrm{H}), 2.23$ (bs, 1H); ${ }^{13} \mathrm{C}$ NMR $\left(100 \mathrm{MHz}, \mathrm{CDCl}_{3}\right) \delta 208.6,141.9,130.9,128.4$, 127.9, 126.8, 115.5, 108.7, 80.0, 71.9; IR (film) 3396, 3029, 2903, 1937, 1810, 1682, 1022, 908, $853 \mathrm{~cm}^{-1}$; HRMS (EI): calcd for $\mathrm{C}_{12} \mathrm{H}_{12} \mathrm{O} 172.0888$, found 172.0888 .

Synthetic procedure of 2-chloro-4-phenyl-3-vinyl-1,3-butadiene (8b): 1-Phenyl-2-vinyl-2,3-butadien-1-ol (51.7 mg, 0.3 $\mathrm{mmol})$ was added to a suspension of $\mathrm{InCl}_{3}(66.4 \mathrm{mg}, 0.3 \mathrm{mmol})$ in dry $\mathrm{CH}_{2} \mathrm{Cl}_{2}(1.2 \mathrm{~mL})$. After being stirred for $10 \mathrm{~min}$ at room temperature under nitrogen atmosphere, the reaction mixture was quenched with saturated $\mathrm{H}_{2} \mathrm{O}$. The aqueous layer was extracted with EtOAc $(3 \times 20 \mathrm{~mL})$ and the combined organic layers were washed with brine. The resulting organic layers were dried over $\mathrm{MgSO}_{4}$, filtered, and concentrated under reduced pressure. The residue was purified by silica gel column chromatography (hexane) to give 2-chloro-4-phenyl-3-vinyl-1,3-butadiene $\mathbf{8 b}$ (41.4 mg, 72\%).

2-Chloro-4-phenyl-3-vinyl-1,3-butadiene (8b): Yellow oil; $Z$ isomer ${ }^{1} \mathrm{H}$ NMR $\left(400 \mathrm{MHz}, \mathrm{CDCl}_{3}\right) \delta 7.54(\mathrm{~d}, J=7.6 \mathrm{~Hz}$, $2 \mathrm{H}), 7.36-7.31(\mathrm{~m}, 3 \mathrm{H}), 6.48(\mathrm{~s}, 1 \mathrm{H}), 6.45(\mathrm{dd}, J=17.1,10.6$ $\mathrm{Hz}, 1 \mathrm{H}), 5.63(\mathrm{~d}, J=1.0 \mathrm{~Hz}, 1 \mathrm{H}), 5.46(\mathrm{~d}, J=17.1 \mathrm{~Hz}, 1 \mathrm{H})$, $5.30(\mathrm{~d}, J=1.0 \mathrm{~Hz}, 1 \mathrm{H}), 5.27(\mathrm{~d}, J=10.6 \mathrm{~Hz}, 1 \mathrm{H}) ;{ }^{13} \mathrm{C} \mathrm{NMR}$ $\left(100 \mathrm{MHz}, \mathrm{CDCl}_{3}\right) \delta 138.6,137.8,135.9,133.0,132.3,129.8$, 128.7, 128.4, 118.5, 116.6; E isomer ${ }^{1} \mathrm{H}$ NMR (400 MHz, $\left.\mathrm{CDCl}_{3}\right) \delta 7.36-7.31(\mathrm{~m}, 3 \mathrm{H}), 7.29-7.24(\mathrm{~m}, 2 \mathrm{H}), 6.88(\mathrm{~s}, 1 \mathrm{H})$, $6.63(\mathrm{dd}, J=17.6,11.1 \mathrm{~Hz}, 1 \mathrm{H}), 5.57(\mathrm{~d}, J=0.7 \mathrm{~Hz}, 1 \mathrm{H}), 5.54$ $(\mathrm{d}, J=0.7 \mathrm{~Hz}, 1 \mathrm{H}), 5.51(\mathrm{~d}, J=17.6 \mathrm{~Hz}, 1 \mathrm{H}), 5.45(\mathrm{~d}, J=11.1$ $\mathrm{Hz}, 1 \mathrm{H}) ;{ }^{13} \mathrm{C} \mathrm{NMR}\left(100 \mathrm{MHz}, \mathrm{CDCl}_{3}\right) \delta 140.8,138.0,136.5$, 135.7, 131.9, 130.1, 128.6, 128.1, 121.0, 116.8; IR (film) 2925, 1734, 1644, 1492, 983, 893, $694 \mathrm{~cm}^{-1}$ HRMS (EI): calcd for $\mathrm{C}_{12} \mathrm{H}_{11} \mathrm{Cl} 190.0549$, found 190.0548 .

Acknowledgments. This work was supported by the National Research Foundation (NRF) of Korea through the National Research Laboratory Program funded by the Ministry of Science and Technology (No. M10600000203-06J0000-20310), by the National Research Foundation of Korea (NRF) grant funded by the Korea government (MEST) (2009-0087013) and by
Korea Sanhak Foundation. This work was supported by the second phase of the Brain Korea 21 Program in 2009. The NMR data were obtained from the central instrumental facility in Kangwon National University.

\section{References}

1. (a) Carruthers, W. Cycloaddition Reactions in Organic Synthesis; Pergamon Press: Oxford, U.K., 1990. (b) Oppolzer, W. In Comprehensive Organic Synthesis; Trost, B. M., Fleming, I., Paquette, L. A., Eds.; Pergamon Press: Oxford, U.K., 1991; Vol. 5, pp 315. (c) Kappe, C. O.; Murphree, S. S.; Padwa, A. Tetrahedron 1997, 53, 14179. (d) Marsault, E.; Toro, A.; Nowak, P.; Deslongchamps, P. Tetrahedron 2001, 57, 4243. (e) Nicolaou, K. C.; Snyder, S. A.; Montagnon, T.; Vassilikogiannakis, G. Angew. Chem., Int. Ed. 2002, 41, 1668 .

2. Horváth, A.; Bäckvall, J.-E. J. Org. Chem. 2001, 66, 8120.

3. Ma, S.; Wang, G. Tetrahedron Lett. 2002, 43, 5723.

4. Deng, Y.; Jin, X.; Ma, S. J. Org. Chem. 2007, 72, 5901.

5. Deng, Y.; Jin, X.; Fu, C.; Ma, S. Org. Lett. 2009, 11, 2169.

6. Cho, Y. S.; Jun. B. K.; Pae, A. N.; Cha, J. H.; Koh, H. Y.; Chang, M. H.; Han, S-Y. Synthesis 2004, 16, 2620.

7. Park, C.; Lee, P. H. Org. Lett. 2008, 10, 3359.

8. Lee, K.; Lee, P. H. Chem. Eur. J. 2007, 13, 8877.

9. Yu, H.; Lee, P. H. J. Org. Chem. 2008, 73, 5183.

10. (a) Seomoon, D.; A. J.; Lee, P. H. Org. Lett. 2009, 11, 2401. (b) Lee, J.-Y.; Lee, P. H. J. Org. Chem. 2008, 73, 7413. (c) Lee, K.; Lee, P. H. Org. Lett. 2008, 10, 2441. (d) Lee, K.; Lee, P. H. Tetrahedron Lett. 2008, 49, 4302. (e) Lee, W.; Kang, Y.; Lee, P. H. J. Org. Chem. 2008, 73, 4326. (f) Seomoon, D.; Lee, P. H. J. Org. Chem. 2008, 73, 1165. (g) Lee, K.; Lee, P. H. Bull. Korean Chem. Soc. 2008, 29, 487. (h) Lee, J.-Y.; Lee, P. H. Bull. Korean Chem. Soc. 2007, 28, 1929. (i) Lee, P. H. Bull. Korean Chem. Soc. 2007, 28, 17. (j) Seomoon, D.; Lee, K.; Kim, H.; Lee, P. H. Chem. Eur. J. 2007, 13, 5197. (k) Lee, P. H.; Lee, K.; Kang, Y. J. Am. Chem. Soc. 2006, 128, 1139.

11. A, J.; Lee, P. H. Bull. Korean Chem. Soc. 2009, 30, 471.

12. (a) Clardy, J.; Forsyth, C. J. J. Am. Chem. Soc. 1990, 112, 3497. (b) Hamze, A.; Provot, O.; Brion, J.-D.; Alami, M. J. Org. Chem. 2007, 72,3868 .

13. Park, J.; Kim, S. H.; Lee, P. H. Org. Lett. 2008, 10, 5067.

14. Choe, Y.; Lee, P. H. Org. Lett. 2009, 11, 1445.

15. Lee, P. H.; Lee, K.; Sung, S.-Y.; Chang, S. J. Org. Chem. 2001, 66, 8846. 